\title{
Heat tolerance in Thai rice varieties
}

\author{
Supansa Sukkeo ${ }^{\mathrm{a}, *}$, Benjavan Rerkasem ${ }^{\mathrm{b}}$, Sansanee Jamjod ${ }^{\mathrm{a}, \mathrm{c}}$ \\ a Department of Plant and Soil Science, Faculty of Agriculture, Chiang Mai University, \\ Chiang Mai 50200 Thailand \\ b Plant Genetic Resource and Nutrition Laboratory, Chiang Mai University, Chiang Mai 50200 Thailand \\ c Lanna Rice Research Centre, Chiang Mai University, Chiang Mai 50200 Thailand
}

*Corresponding author, e-mail: su_pan_sas@hotmail.com

Received 10 Dec 2016

Accepted 19 Jun 2017

\begin{abstract}
Rice yield reduction at high temperature is a serious problem in the tropics and is likely to worsen with climate change. Temperature-tolerant rice varieties would be highly desirable in areas at risk of extreme temperatures. This study evaluated 7 modern Thai rice varieties with a wet season planting on 1st July (Planting date 1 (PD1)), and 3 dry season plantings 9th January (PD2), 23rd January (PD3), and 6th February (PD4), in 2009. The mean minimum and maximum temperature to which the crop was exposed during the different phases of reproductive growth were 20.6-24. $1^{\circ} \mathrm{C}$ and $33.3-36.9^{\circ} \mathrm{C}$ for the 30 days before anthesis, $22.1-24.4^{\circ} \mathrm{C}$ and $32.1-37.6^{\circ} \mathrm{C}$ at anthesis, $22.5-24.0^{\circ} \mathrm{C}$ and $34.3-37.5^{\circ} \mathrm{C}$ for the 30 days after anthesis. Grain yields of all the varieties were lower in PD2-PD4 than in PD1. The dry season yield depression separated the rice varieties into two classes: sensitive varieties with a dry season yield of about half of the wet season yield (SPT1, NP1, R258 and SKN1), and tolerant varieties which showed much less seasonal difference in yield (RD10, CNT1, and SPR1). Sensitive and tolerant varieties were also differentiated by the way in which the proportion of unfertilized spikelets, number of spikelets per panicle, and proportion of filled grain correlated with the temperature during the relevant period of development, with the tolerant varieties being less responsive to rising temperature than the sensitive varieties. This study demonstrates a range of heat sensitive and tolerance already in existence among modern Thai rice varieties. We found a complex physiology of the high temperature response of rice, in which grain yield may be adversely affected during panicle development, anthesis, and during grain filling. The genes and QTLs for heat tolerance may need to be separately identified.
\end{abstract}

KEYWORDS: panicle development, fertilization, grain filling

\section{INTRODUCTION}

High temperature is a threat to rice production in tropical areas. The risk of yield loss increases with rising global temperature due to climate change ${ }^{1}$ particularly during the dry season in monsoonal Asia. Yield reduction by high temperature over $35^{\circ} \mathrm{C}$ has been reported in various crop species such as wheat, soya bean, barley, maize ${ }^{2-4}$, and rice ${ }^{5,6}$. Rice yield reduction caused by high temperature occurs in irrigated systems ${ }^{7}$ and is particularly severe during the dry season ${ }^{8}$. There was a report that for every $1^{\circ} \mathrm{C}$ increase of the mean minimum temperature over $22^{\circ} \mathrm{C}$ the yield of IR72, one of Asia's megavarieties, was depressed by $10 \%{ }^{9}$. High temperature affects rice yield through various growth and development stages ${ }^{10}$. High temperature during the early reproductive stage depresses the number of spikelets per panicle ${ }^{11}$, which is associated with fewer primary and secondary rachis-branches ${ }^{12}$. The number of spikelets per panicle is the major fac- tor that limits the yield by reducing the sink size ${ }^{13}$, leading to lower yield producing capacity. High temperature during anthesis adversely affects the fertilization process ${ }^{14}$. During pollination, temperatures higher than $34-35^{\circ} \mathrm{C}$ increase empty grain ${ }^{8}$. High temperature impedes anther dehiscence and pollen release ${ }^{15}$, causing fewer pollen grains landing on the stigma ${ }^{16,17}$ with the result of lower probability for successful fertilization even though only one germinated pollen is required ${ }^{6}$. The risk of high temperature affecting yield through grain filling was demonstrated in an earlier report that rice yield declined with increasing of temperature during the 30-day period after anthesis ${ }^{18}$.

As a strategy for adaptation to high temperature, heat tolerant rice varieties providing desirable yield under high temperature is necessary. Thus effective screening methods are important to identify heat tolerant rice variety. Although different genotypes for heat tolerance have been reported in the amount of pollen, pollen germinated on 


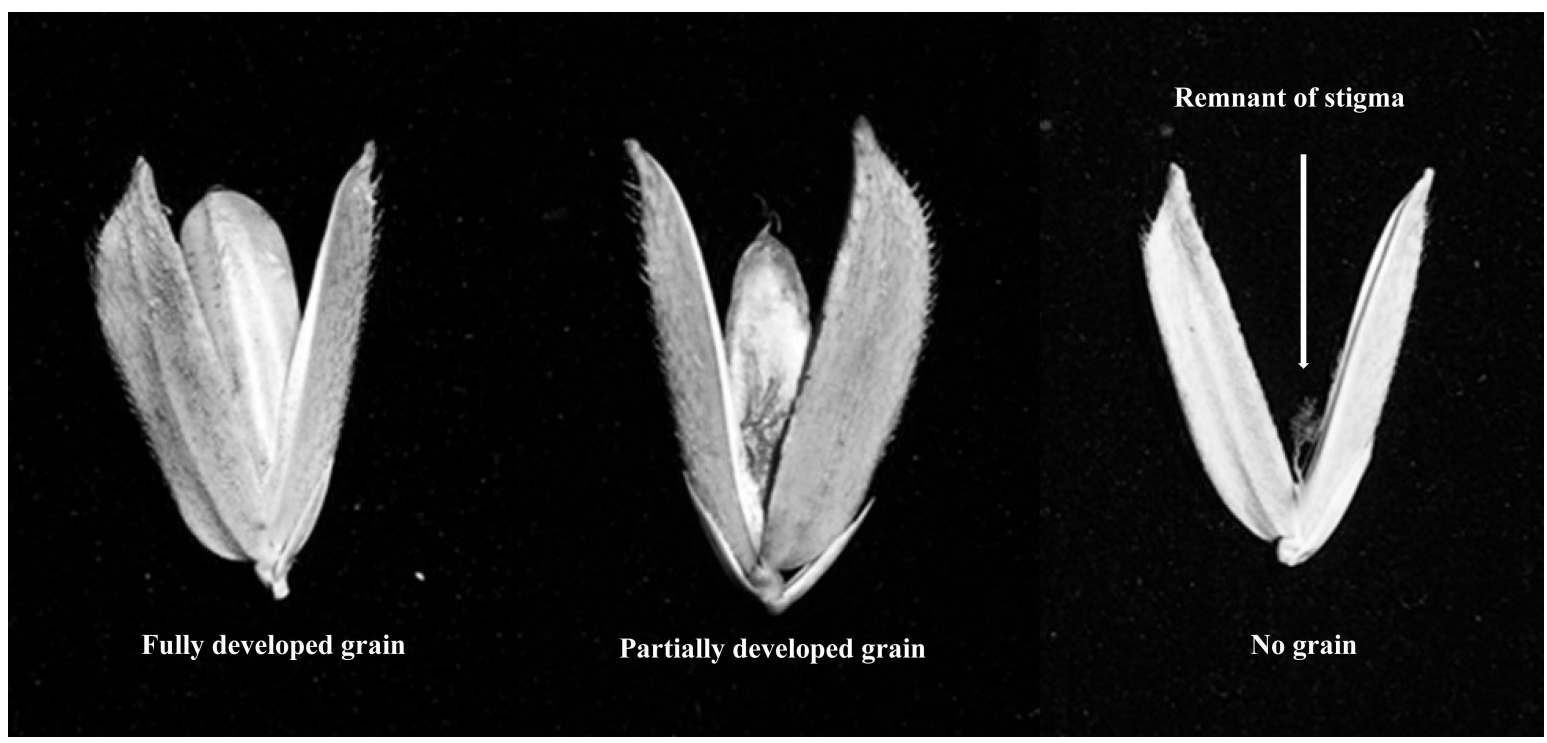

Fig. 1 Rice spikelet at maturity: fertilized and filled (left), fertilized but unfilled (centre), and unfertilized (right).

stigma, pollen tube length ${ }^{16,19,20}$, spikelet fertility $^{21,22}$, filled grain ${ }^{23}$, seed set $^{24}$, and empty grain ${ }^{8}$, these heat tolerant genotypes were not clear in terms of using them as the selection criteria for heat tolerant rice variety. The objectives of this study were (1) to examine the effects of high temperature on different yield forming processes among seven rice varieties and (2) to obtain screening method for heat tolerance in rice.

\section{MATERIALS AND METHODS}

\section{Genotypes}

Seven Thai rice genotypes used in this study comprised San-pah-tawng 1 (SPT1), Neaw Phrae 1 (NP1), R258, Skon Nakhon 1 (SKN1), RD10, Chai Nat 1 (CNT1), and Suphan Buri 1 (SPR1). All genotypes have a semi-dwarf plant type, are photoperiod insensitive, lowland rice, and popularly grown in irrigated areas. NP1, R258, SKN1, and RD10 were the varieties most commonly grown in the North and Northeast while CNT1 and SPR1 were commonly grown in the Central Plain.

\section{Experimental procedures}

The rice genotypes were grown in four planting dates, including one wet season planting on July 1 (PD1), and 3 dry season plantings 9th January (PD2), 23rd January (PD3), and 6th February (PD4), in 2009, aiming to subject the plant to different temperature regimes during their reproductive development. For each planting date, 7-day old seedlings of each genotype were transplanted into plastic undrained pots $(30 \mathrm{~cm}$ diameter and $30 \mathrm{~cm}$ depth) at 10 per pot, arranged in a completely randomized design with 3 replicated pots. Fertilizer applied included $0.18 \mathrm{~g} \mathrm{P} /$ pot and $0.22 \mathrm{~g} \mathrm{~N} /$ pot at 20 days after transplanting and $0.2 \mathrm{~g} \mathrm{~N} /$ pot at 45 at 60 days after transplanting.

Daily maximum and minimum temperature were measured every 5 min by Ebro EBI20-TH1 data locker (Ebro Electronic GmbH \& Co. KG) placed above the canopy over the whole experimental period. At anthesis, flowering date was recorded for individual plants. This study focus on different yield forming processes; hence, the effects of average maximum and minimum temperature were divided into three periods: before anthesis, anthesis, and after anthesis. At physiological maturity, plant height and number of panicles per plant were determined. The first two panicles of each plant were collected to evaluate number of spikelets per panicle, number of filled grains, fertilized but unfilled/partially filled and unfertilized spikelets (Fig. 1). Proportion of unfertilized spikelet $U_{\mathrm{s}}$, proportion of filled grain $F_{\mathrm{g}}$, and proportion of fertilized spikelet $F_{\mathrm{s}}$ were calculated as

$$
\begin{aligned}
& U_{\mathrm{s}}=\frac{\text { no. unfertilized spikelets }}{\text { no. spikelets per panicle }}, \\
& F_{\mathrm{g}}=\frac{\text { no. filled grain }}{\text { no. spikelets per panicle }}, \\
& F_{\mathrm{s}}=F_{\mathrm{g}}+\frac{\text { no. fertilized but unfilled grain }}{\text { no. spikelets per panicle }} .
\end{aligned}
$$




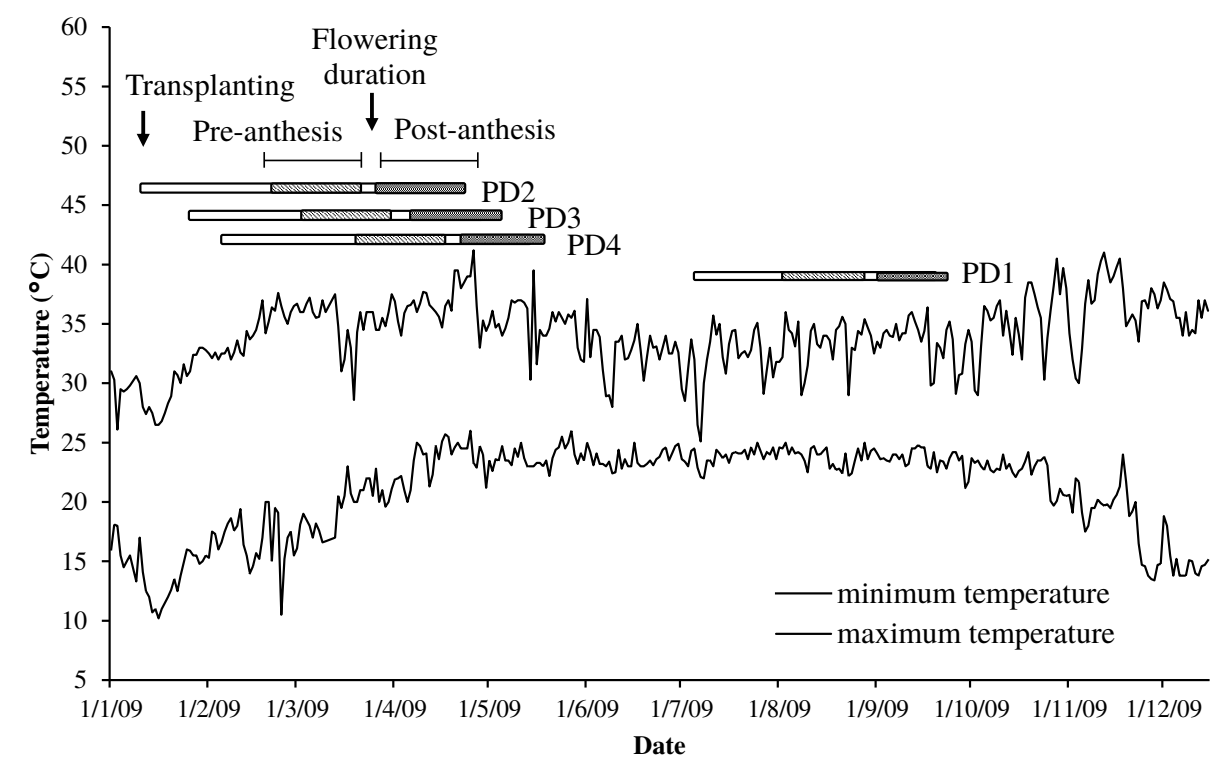

Fig. 2 Maximum and minimum temperature during the experiment with wet season planting (PD1) and 3 dry season plantings (PD2-PD4) and timing of transplanting and duration of reproductive developmental phases indicated.

Table 1 Average minimum and maximum temperature ranges during the 30 days before anthesis, during anthesis, and 30 days after anthesis of 7 rice varieties in 4 plantings in 2009 growing season.

\begin{tabular}{|c|c|c|c|c|c|c|c|}
\hline \multirow{2}{*}{$\begin{array}{l}\text { Planting } \\
\text { date }\end{array}$} & \multirow[t]{2}{*}{ Transplanting } & \multirow[t]{2}{*}{ Expected flowering } & \multirow[t]{2}{*}{ Actual flowering } & \multicolumn{4}{|c|}{ Temperature $\left({ }^{\circ} \mathrm{C}\right)$} \\
\hline & & & & & Before & Anthesis & After \\
\hline \multirow[t]{2}{*}{ PD1 } & 1st Jul & 1st-21st Oct & 9th-20th Sep & $\min$ & $23.6-23.8$ & $22.1-23.1$ & $22.5-23.4$ \\
\hline & & & & $\max$ & $33.4-33.9$ & $32.1-33.2$ & $34.3-35.6$ \\
\hline \multirow[t]{2}{*}{ PD2 } & 9th Jan & 9th-29th Apr & 4th-20th Apr & $\min$ & $20.6-21.6$ & $22.6-24.2$ & $23.9-24.0$ \\
\hline & & & & $\max$ & $35.1-35.3$ & $35.4-37.3$ & $35.8-36.0$ \\
\hline \multirow[t]{2}{*}{ PD3 } & 23rd Jan & 23rd Apr-13th May & 15th Apr-10th May & $\min$ & $23.1-23.8$ & $23.4-24.0$ & $23.6-23.9$ \\
\hline & & & & $\max$ & $36.8-36.9$ & $35.3-37.6$ & $36.5-36.6$ \\
\hline \multirow[t]{2}{*}{ PD4 } & 6th Feb & 6th-27th May & 30th Apr-22nd May & $\min$ & $23.6-24.1$ & $22.6-24.4$ & $23.7-23.8$ \\
\hline & & & & $\max$ & $36.0-36.9$ & $35.3-37.2$ & $36.5-37.5$ \\
\hline
\end{tabular}

Data were analysed by ANOVA with appropriate transformations. Means were compared by LSD at $p<0.05$. Regression analysis were conducted to relate grain yield and yield components, and to relate number of spikelets, fertilization success or failure, and grain filling to variation in temperature, separately for heat tolerant and sensitive varieties.

\section{RESULTS}

\section{Maximum and minimum temperatures}

Temperatures during the experiment ranged from $19.6-23.0^{\circ} \mathrm{C}$ for the daily mean minimum $(02: 00$ $05: 00$ ) and from $34.0-35.4^{\circ} \mathrm{C}$ for the daily mean maximum (10:00-14:00) (Fig. 2). For the 30day period before anthesis, the minimum temperature ranged from $20.6^{\circ} \mathrm{C}$ to $24.1^{\circ} \mathrm{C}$ and the maximum temperature ranged from $33.4^{\circ} \mathrm{C}$ to $36.9^{\circ} \mathrm{C}$
(Table 1). During anthesis, which lasted about 7 days, the minimum temperature ranged from $22.1^{\circ} \mathrm{C}$ to $24.4^{\circ} \mathrm{C}$ and the maximum temperature ranged from $32.1{ }^{\circ} \mathrm{C}$ to $37.6^{\circ} \mathrm{C}$. In the 30 days period following anthesis the minimum temperature ranged from $22.5^{\circ} \mathrm{C}$ to $24.0^{\circ} \mathrm{C}$ and the maximum temperature ranged from $34.3^{\circ} \mathrm{C}$ to $37.5^{\circ} \mathrm{C}$. Average maximum and minimum temperatures were different for the four planting dates before anthesis, anthesis, and after anthesis (Fig. 3).

Effects of planting date on flowering date, yield, and yield components

Interaction between genotype and planting date significantly affected the flowering date, number of spikelets per panicle, proportion of unfertilized spikelet, proportion of fertilized spikelets, and pro- 

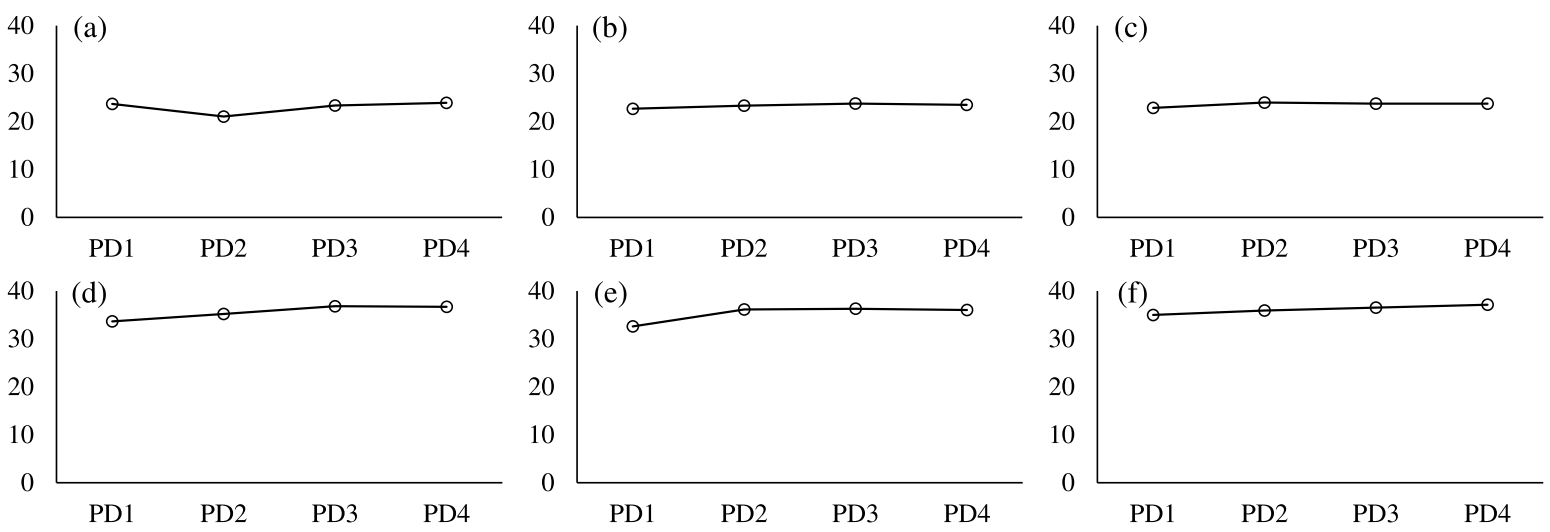

Fig. 3 Differences in $(a-c)$ minimum and $(d-f)$ maximum mean temperature for four planting dates: (a,d) before anthesis, (b,e) anthesis, and (c,f) after anthesis. Flowering duration of PD1-PD4 were 9th-20th September, 4th-20th April, 15th April-10th May, and 30th April-22nd May 2009, respectively.

Table 2 ANOVA of night traits of seven rice varieties grown at different four planting dates.

\begin{tabular}{lccc}
\hline Traits & Genotype (G) & PD & G $\times$ PD \\
\hline Plant height (cm) & $* * *$ & $* * *$ & $\mathrm{~ns}$ \\
Flowering date & $* * *$ & $* * *$ & $* * *$ \\
Number of panicles/plant & $*$ & $\mathrm{~ns}$ & $\mathrm{~ns}$ \\
Number of spikelets/panicle & $* * *$ & $* * *$ & $* * * *$ \\
Fertilized spikelets (\%) & $* * *$ & $* * *$ & $* * *$ \\
Unfertilized spikelets (\%) & $* * *$ & $* * *$ & $* * *$ \\
Filled grain (\%) & $* * *$ & $* * *$ & $* * *$ \\
Number of grains/panicle & $* * *$ & $* * *$ & $* * *$ \\
100-grain weight (g) & $*$ & $\mathrm{~ns}$ & $\mathrm{~ns}$ \\
Yield (g/plant) & $* * *$ & $* * *$ & $* * *$
\end{tabular}

$*, * * *=$ significant difference at $p<0.05$ and $0.001 ;$ $\mathrm{ns}=$ not significant, $p>0.05$.

portion of filled grain $(p<0.001)$ (Table 2). Flowering date was significantly different between varieties within planting date and different planting date. Grain yield and yield components of all 7 rice varieties were highest in the wet season planting, with significant varietal differences in dry season depression of the yield and its components.

The highest grain yield in all 7 varieties was achieved with PD1, the wet season planting, the extent to which the yield was depressed in the dry season plantings varied among the varieties (Fig. 4). The largest depression of around 50\% in PD4 was found in the varieties SPT1, NP1, R258, and SKN1, while the dry season depression in RD10 and CNT1 was $15-20 \%$, and even smaller for SPR1. The varieties also differed in their yield response to the different dry season plantings. In SPT1, NP1, and R258, the yield from PD2, PD3, and PD4 were lower

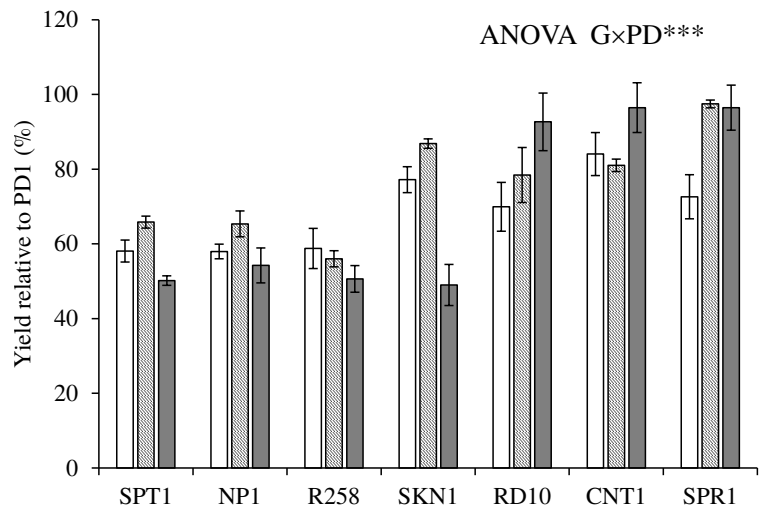

Fig. 4 Effect of planting date on dry season yield (PD2PD4) relative to wet season. An arcsine transformation was used before analysis by ANOVA. The bars indicate mean \pm SE.

than PD1 to about the same extent. RD10, CNT1, and SPR1, on the other hand, had similar yield in PD1 and PD4, and in SPR1 significantly lower yield was produced only in PD2.

All the rice varieties flowered later in PD2PD4 than in PD1 by about 10 days later in SPT1, NP1, and R258, while the others were 5 days later compared with PD1 (Fig. 5a). The highest number of spikelets per panicle in all varieties was found in PD1, with 100-140 spikelets/panicle, but the varieties differed in the degree to which the number of spikelets was depressed in the dry season plantings (Fig. 5b). The number of spikelets in SPT1, NP1, and R258 suffered the greatest dryseason depression by $20-30 \%$, while RD10, CNT1, and SPR1 were much less affected.

All 7 rice varieties achieved the greatest fertil- 

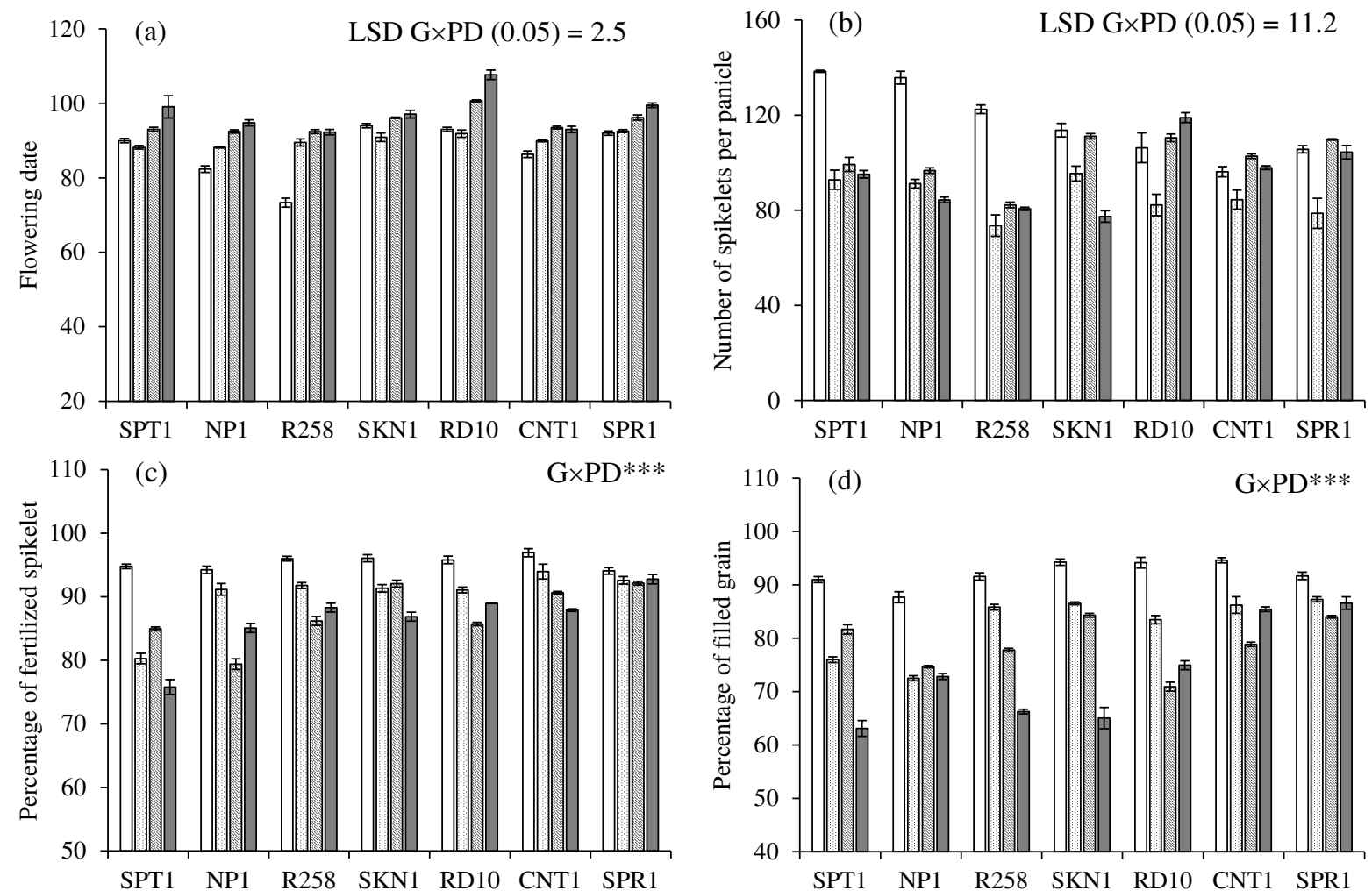

Fig. 5 Effect of planting date (PD1-PD4) and genotype on (a) flowering date, (b) number of spikelets per panicle, (c) proportion of fertilized spikelets, and (d) proportion of filled grain. An arcsine transformation was used for the proportion of fertilized spikelet and filled grain before analysis by ANOVA. Bars indicate mean \pm SE.

ization success in PD1, with 94-97\% of the spikelet fertilized, with different degrees of failure among the varieties in PD2-PD4 (Fig. 5c). The variety SPR1 exhibited no effect of planting date on the proportion fertilized spikelets, while dry season depression in spikelet fertility in SPT1 and NP1 was $30-50 \%$, and $10-15 \%$ in the remaining varieties.

The highest proportion of filled grain at 8895\% was achieved in PD1 for all 7 varieties, but the varieties differed in the degree to which their grain filling was depressed in the dry season plantings (Fig. 5d). Dry season depression in grain filling was minor in the varieties CNT1 and SPR1, while the proportion of filled grain in the dry season plantings was depressed by $20 \%$ in NP1 and RD10, and by $50 \%$ in SPT1, R258, and SKN1.

Grain yield correlated positively with number of spikelets per panicle $(c=0.80, p<0.001)$, number of grain per panicle ( $c=0.88, p<0.001$ ), proportion of filled grain $(c=0.62, p<0.001)$, and 100grain weight $(c=0.25, p<0.01)$, but negatively with proportion of unfertilized spikelets $(c=-0.55$, $p<0.001$ ) (Table 3).
Table 3 Correlation between yield and growth parameters of seven rice varieties grown at four planting dates.

\begin{tabular}{lrc}
\hline Growth parameter & \multicolumn{2}{c}{ Yield } \\
\cline { 2 - 3 } & Correlation $(c)$ & $p$-value \\
\hline Flowering date & -0.36 & $<0.001$ \\
Plant height & 0.04 & $\mathrm{~ns}^{*}$ \\
Number of panicles/plant & -0.03 & $\mathrm{~ns}^{*}$ \\
Number of spikelets/panicle & 0.80 & $<0.001$ \\
Number of grains/panicle & 0.88 & $<0.001$ \\
\% unfertilized spikelet & -0.55 & $<0.001$ \\
\% filled grain & 0.62 & $<0.001$ \\
100-grain weight & 0.25 & $<0.01$ \\
\hline
\end{tabular}

"ns $=$ not significant at $p<0.05$.

\section{Relating yield and components to the temperature}

According to the level of dry season depression in yield and yield components, SPT1, NP1, R258, and SKN1 were classified into a heat sensitive group, and RD10, CNT1, and SPR1 into a heat tolerant. The groups were found to be differentiated by the way in 

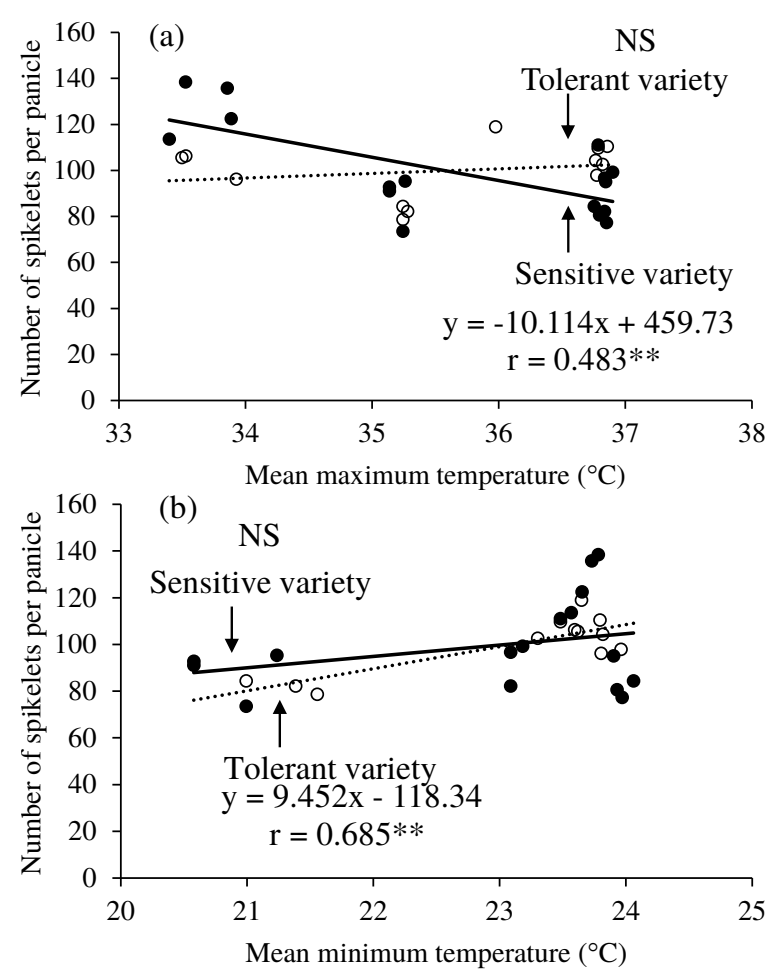

Fig. 6 Relationships between (a) mean maximum temperature, (b) mean minimum temperature, 30 days before anthesis, and number of spikelets per panicle of sensitive (black circle) and tolerant (open circle) group of varieties.

which their number of spikelets, fertilization success and grain filling varied with temperature.

The increase in daily maximum temperature during the 30 days before anthesis from 33.5 to $37.0^{\circ} \mathrm{C}$ was associated with fewer spikelets per panicle in the sensitive varieties (slope $=-10.11, p<$ 0.01 ) but not in the tolerant varieties. The increase in the minimum temperature was associated with increased spikelet number in the tolerant varieties (slope $=9.45, p<0.01$ ) but not in the sensitive varieties (Fig. 6b).

The proportion of unfertilized spikelets generally increased with increasing daily maximum temperature, but more sharply in the sensitive (slope $=$ $3.19, p<0.001$ ) than in the tolerant (slope $=1.22$, $p<0.05$ ) varieties (Fig. 7a). No relationship was observed between the daily minimum temperature at anthesis and spikelet fertilization (Fig. 7b).

The proportion of filled grain generally declined with increasing daily maximum and minimum temperature during the 30 days after anthesis, but with a significant difference among the rice varieties (Fig. 8). The increase in daily maximum temperature from $34.3-37.5^{\circ} \mathrm{C}$ was associated with
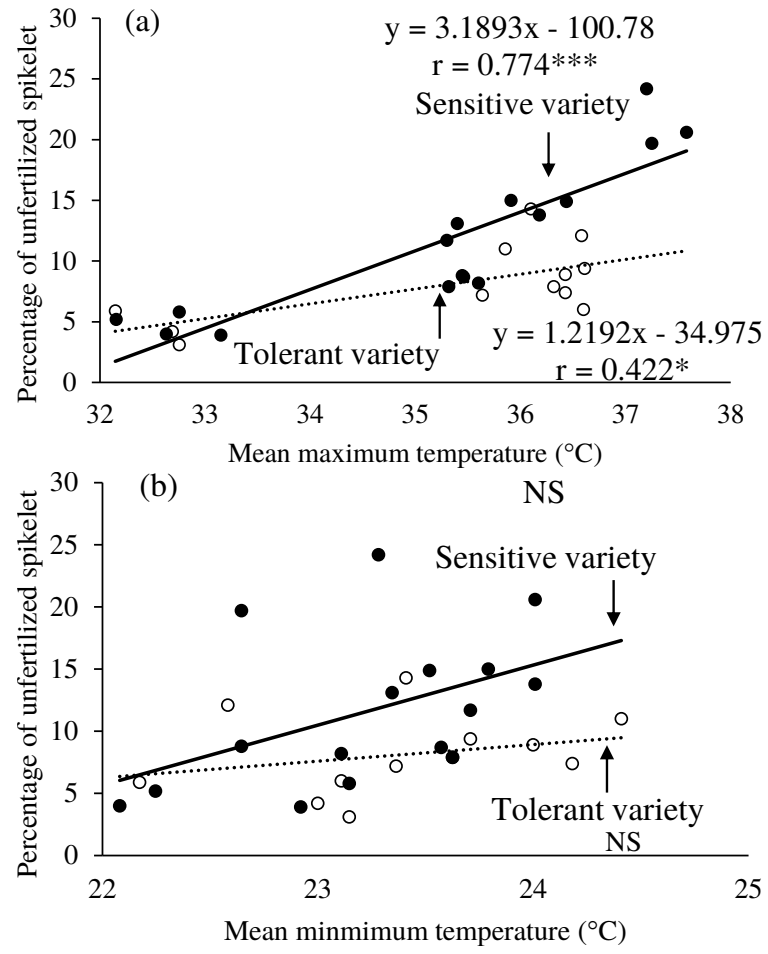

Fig. 7 Relationships between (a) mean maximum temperature, (b) mean minimum temperature, at anthesis, and proportion of unfertilized spikelets of sensitive $(\bullet)$ and tolerant (o) group of varieties.

a sharper decline in proportion of filled grain in the sensitive (slope $=-9.87, p<0.001$ ) than in the tolerant (slope $=-4.47, p<0.05$ ) varieties. Similarly to the minimum temperature, the increase in minimum temperature from $22.5-24.0^{\circ} \mathrm{C}$ was associated with a sharper decline in the proportion of filled grain in the sensitive varieties (slope $=-12.98, p<$ 0.01 ) than the tolerant varieties (slope $=-9.20$, $p<0.05$ ) (Fig. 8b).

\section{DISCUSSION}

By varying planting date in the wet and dry season, the rice plants were subjected to temperatures that varied from optimum to critically high for its development and yield. The optimum temperature for anthesis in rice was $30-33^{\circ} \mathrm{C}$ and critical high at $35-36^{\circ} \mathrm{C}$ depending on the variety ${ }^{25}$. In this study the temperature during PD1, the wet season when most rice in Thailand is grown, was within the optimal range, but the temperature during the dry season planting PD2-PD4 rose to the critically high ranges. This study shows that rice yield from the dry season plantings were lower than the wet season planting, with the degree of yield depression that 

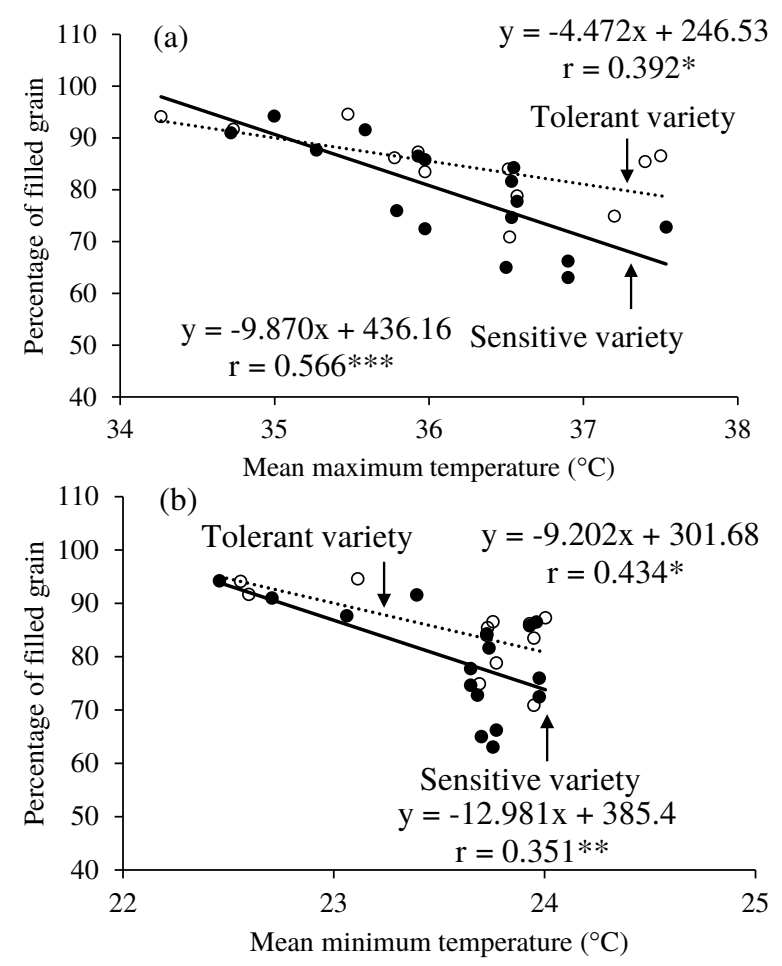

Fig. 8 Relationships between (a) mean maximum temperature, (b) mean minimum temperature, 30 days after anthesis, and proportion of filled grain of sensitive $(\bullet)$ and tolerant (o) group of varieties.

differed among the rice varieties. This is in contrast to the generally held view that rice yield in the tropics is significantly higher in the dry season than in the wet season ${ }^{26,27}$. The higher dry season yield has been attributed experimentally to higher radiation with less cloud cover associated with higher biomass ${ }^{28,29}$. The present results demonstrate how the seasonal variation in grain yield is associated with the number of spikelets and the proportion at which they are fertilized and filled. The variation in tolerance to high temperature among the rice varieties in this study was indicated by the different degree to which these components of the yield were associated with the rise in temperature. Out of the seven rice varieties, high temperature largely affected SPT1, NP1, R258, and SKN1 with $30-50 \%$ yield reduction varied with variety. The most affected was SPT1 while the less affected were RD10, CNT1, and SPR1 with lower yield reduction of $10-15 \%$ and much less for SPR1. Rice yield has been previously reported to be depressed when the number of spikelets per panicle declines with rising night temperature ${ }^{9,29}$. As for the failure of the fertilization process from depression of pollen viability ${ }^{30}$, the number of pollen germinating on the stigma is associated with high daytime temperature $^{17,20,30}$. This study demonstrates how the yield of different rice varieties may vary differently with rising temperature through variations in the relationship between temperature and their yield forming process from panicle development, to fertilization, and grain filling.

During panicle development, the increase in maximum temperature (i.e., daytime temperature) before anthesis was associated with decreasing number of spikelets per panicle in the sensitive varieties but not in the tolerant varieties. The lack of a relationship between the minimum temperature (i.e., night-time temperature) before anthesis and the number of spikelets (Fig. 6) suggests that all seven Thai rice varieties in this study may be more tolerant to increasing of night temperature than IR72, the variety studied in Ref. 9. The effect of high temperature on fertilization failure in the sensitive varieties in this study was consistent with most studies on the effect of high temperature on yield reduction and genotypic variation in hightemperature tolerance, which usually focused on the fertilization process ${ }^{17,31}$. Furthermore, the heat tolerance in the fertilization process of SPR 1 and CNT1 and the heat sensitivity in SPT1 have been reported $^{30}$. During anthesis the proportion of unfertilized spikelet of all varieties increased when the maximum temperature increased, but the lack of relationship with minimum temperature is to be expected as pollination takes place in the daytime. This serves as a reminder of the need to focus on the temperature specific to each yield forming process in order to identify the relevant physiological basis for tolerance and controlling genes or QTLs.

The negative correlation between the proportion of filled grain with both maximum and minimum temperature suggests that after fertilization has been successfully completed, high temperature may still depress the yield through the adverse effect on grain filling (Fig. 8). To identify the particular yield forming process that is adversely affected by high temperature, it would be necessary to distinguish between unfertilized spikelets, recognized by remnant of the stigma, and fertilized but unfilled or partially-filled grain, indicated by small undeveloped grain and complete disappearance of the stigma (Fig. 1). Normally fertilization is complete within 5-6 h after pollination and the kernel appears after 2-3 days ${ }^{32}$. However, this does not mean that all grain that are fertilized are then filled. The 
filling of fertilized grains is determined by the supply of photosynthates ${ }^{33}$. The evaluation of fertilized and filled grain has therefore enabled the sensitivity or tolerance to temperature of two very different process, i.e., fertilization of the gametes and the capacity to supply photosynthates, to be precisely identified. Furthermore, this should enable relevant genes and QTLs as well as more varieties with tolerance at the most critical time to be more precisely identified. Thus contributions can be made towards adapting rice to climate change.

In conclusion, this study found variation in heat tolerance among modern Thai rice varieties. The tolerant and sensitive varieties were distinguished by differential responses to rising temperature during three main yield forming processes, i.e., the number spikelets before anthesis, the success in fertilization of the gametes during anthesis, and grain filling in the period after anthesis. To identify heat tolerance at specific stages, specific time, and relevant traits, emphasis needs to be placed on the number of spikelets per panicle at 30 days before anthesis, number of fertilized spikelet during anthesis, and number of filled grain at 30 days after anthesis.

Acknowledgements: This work is part of Sukkeo's doctoral thesis, and was supported by the Office of the Higher Education Commission, Thailand under the program "Strategic Scholarships for Frontier Research Network for the PhD Programme, Thai Doctoral Degree". Support from the National Research University Project of Thailand's Commission on Higher Education is also gratefully acknowledged.

\section{REFERENCES}

1. McCarthy JJ, Canziani OF, Leary NA, Dokken DJ, White KS (2001) Climate Change 2001: Impacts, Adaptation and Vulnerability, Cambridge Univ Press, Cambridge, UK.

2. Badu-Apraku B, Hunter RB, Tollenaar M (1983) Effect of temperature during grain filling on whole plant and grain yield in maize (Zea mays L.). Can $J$ Plant Sci 63, 357-63.

3. Gibson LR, Mullen RE (1996) Influence of day and night temperature on soybean seed yield. Crop Sci 36, 98-104.

4. Wheeler TR, Hong TD, Ellis RH, Batts GR, Morison JIL, Hadley P (1996) The duration and rate of grain growth, and harvest index, of wheat (Triticum aestivum L.) in response to temperature and $\mathrm{CO}_{2} . J \operatorname{Exp}$ Bot 47, 623-30.

5. Baker JT, Allen LH Jr, Boote KJ (1992) Response of rice to carbon dioxide and temperature. Agr Forest Meteorol 60, 153-66.
6. Satake T, Yoshida S (1978) High temperatureinduced sterility in indica rice at flowering. Crop Sci 47, 6-17.

7. Welch JR, Vincent JR, Auffhammer M, Moya PF, Dobermann A, Dawe D (2010) Rice yields in tropical/subtropical Asia exhibit large but opposing sensitivities to minimum and maximum temperatures. Proc Natl Acad Sci USA 107, 14562-7.

8. Osada A, Sasiprapa V, Rahong M, Dhammanuvong S, Chakrabondho H (1973) Abnormal occurrence of empty grains of indica rice plants in the dry, hot season in Thailand. Proc Crop Sci Soc Jpn 42, 103-9.

9. Peng S, Huang J, Sheehy JE, Laza RC, Visperas RM, Zhong X, Centeno GS, Khush GS, Cassman KG (2004) Rice yields decline with higher night temperature from global warming. Proc Natl Acad Sci USA 101, 9971-5.

10. Wassmann R, Jagadish SVK, Heuer S, Ismail A, Redona E, Serraj R, Singh RK, Howell G, et al (2009) Chapter 2 Climate change affecting rice production: the physiological and agronomic basis for possible adaptation strategies. In: Sparks DL (ed) Advances in Agronomy vol 101, Academic Press, pp 59-122.

11. Kobayashi S, Fukuta Y, Yagi T, Sato T, Osaki M, Khush GS (2004) Identification and characterization of quantitative trait loci affecting spikelet number per panicle in rice (Oryza sativa L.). Field Crop Res 89, 253-62.

12. Kobayasi K (2004) Effects of temperature on the development of rice panicles. Bull Fac Life Environ Sci Shimane Univ 9, 7-12.

13. Matsushima S (1995) Physiology of high-yielding rice plants from the viewpoint of yield components. In: Matsuo T, Kumazawa K, Ishii R, Ishihara K, Hirata $\mathrm{H}$ (eds) Science of the Rice Plant. Volume 2: Physiology, Food and Agriculture Policy Research Center, Tokyo, pp 737-66.

14. Nakagawa H, Horie T, Matsui T (2003) Effects of climate change on rice production and adaptive technologies. In: Mew TW, Brar DS, Peng S, Dawe D, Hardy B (eds) Rice Science: Innovations and Impact for Livelihood, International Rice Research Institute (IRRI), pp 635-58.

15. Matsui T, Omasa K, Horie T (2000) High temperature at flowering inhibit swelling of pollen grain, a driving force for thecae dehiscence in rice (Oryza sativa L.). Plant Prod Sci 3, 430-4.

16. Matsui T, Omasa K, Horie T (2001) The difference in sterility due to high temperatures during the flowering period among japonica-rice varieties. Plant Prod Sci 4, 90-3.

17. Prasad PVV, Boote KJ, Allen JLH (2006) Adverse high temperature effects on pollen viability, seed-set, seed yield and harvest index of grain-sorghum [Sorghum bicolor (L.) Moench] are more severe at elevated carbon dioxide due to higher tissue temperatures. Agr Forest Meteorol 139, 237-51. 
18. Islam M, Morison J (1992) Influence of solar radiation and temperature on irrigated rice grain yield in Bangladesh. Field Crop Res 30, 13-28.

19. Jagadish SVK, Muthurajan R, Oane R, Wheeler TR, Heuer S, Bennett J, Craufurd PQ (2009) Physiological and proteomic approaches to address heat tolerance during anthesis in rice (Oryza sativa L.). $J$ Exp Bot 61, 143-56.

20. Mackill DJ, Coffman WR, Rutger JN (1982) Pollen shedding and combining ability for high temperature tolerance in rice. Crop Sci 22, 730-3.

21. Jagadish S, Craufurd P, Wheeler T (2007) High temperature stress and spikelet fertility in rice (Oryza sativa L.). J Exp Bot 58, 1627-35.

22. Prasad PVV, Pisipati SR, Mutava RN, Tuinstra MR (2008) Sensitivity of grain sorghum to high temperature stress during reproductive development. Crop Sci 48, 1911-7.

23. Ziska L, Manalo P (1996) Increasing night temperature can reduce seed set and potential yield of tropical rice. Funct Plant Biol 23, 791-4.

24. Madan P, Jagadish SVK, Craufurd PQ, Fitzgerald M, Lafarge T, Wheeler TR (2012) Effect of elevated $\mathrm{CO}_{2}$ and high temperature on seed-set and grain quality of rice. $J$ Exp Bot 63, 3843-52.

25. Yoshida S (1978) Tropical Climate and Its Influence on Rice, IRRI, Los Banos, Philippines.

26. De Datta SK (1981) Principles and Practices of Rice Production,. John-Wiley \& Sons, Inc., Singapore.

27. Yoshida S (1981) Fundamentals of Rice Crop Science, IRRI, Los Banos, Philippines.

28. De Datta SK, Zarate PM (1970) Environmental conditions affecting the growth characteristics, nitrogen response and grain yield of tropical rice. Int $J$ Biometeorol 14S, 71-89.

29. Zhang Y, Tang Q, Peng S, Zou Y, Chen S, Shi W, Qin J, Laza MRC (2013) Effects of high night temperature on yield and agronomic traits of irrigated rice under field chamber system condition. Aust J Crop Sci 7, 7-13.

30. Jongjaidee J, Lordkaew S, Konsaeng S, Jamjod S, Rerkasem B (2010) Effects of high temperature on pollen viability and fertilization in Thai rice varieties. J Agr 26, 29-35, [in Thai].

31. Jagadish SVK, Craufurd PQ, Wheeler TR (2008) Phenotyping parents of mapping populations of rice for heat tolerance during anthesis. Crop Sci 48, 1140-6.

32. Krishnan S, Dayanandan P (2003) Structural and histochemical studies on grain-filling in the caryopsis of rice (Oryza sativa L.). $J$ Biosci 28, 455-69.

33. Moldenhauer K, Wilson CE Jr, Counce P, Hardke J (2013) Rice growth and development. In: Hardke JT (ed) Arkansas Rice Production Handbook-MP192, Univ of Arkansas Division of Agriculture, Little Rock, Arkansas, pp 9-20. 